\title{
Evaluation of Addiction among Students in First Year of a French University
}

\author{
Godet Andrea1*, Deschamps Frédéric², Koffi Marie-Emmanuelle², Kueny Guillaume², \\ Calmus Caroline ${ }^{3}$, Dramé Moustapha ${ }^{4}$, Godet Sébastien ${ }^{5}$ \\ ${ }^{1}$ Centre Addictologique Michel Fontan, Centre Hospitalier Bélair, Charleville-Mézières, France \\ ${ }^{2}$ Service Universitaire de Médecine Préventive et de Promotion de Santé, Université Reims \\ Champagne-Ardenne, Reims, France \\ ${ }^{3}$ Observatoire du Suivi de l'Insertion Professionnelle et d'Evaluation, Université Reims Champagne-Ardenne, \\ Reims, France \\ ${ }^{4}$ Unité d'Aide Méthodologique, Université Reims Champagne-Ardenne, Reims, France \\ ${ }^{5}$ Unité de Soins pour Adolescents, Centre Hospitalier Bélair, Charleville-Mézières, France \\ Email: *andrea godet@hotmail.fr
}

Received 28 November 2015; accepted 26 January 2016; published 29 January 2016

Copyright (C) 2016 by authors and Scientific Research Publishing Inc.

This work is licensed under the Creative Commons Attribution International License (CC BY). http://creativecommons.org/licenses/by/4.0/

(c) (i) Open Access

\begin{abstract}
Background: We aimed to describe addictive behaviours and identify risk factors for addiction among students in their first year of university, which is known to represent a stressful situation conducive to the emergence of addictive behaviours. Methods: Ongoing cross-sectional survey among first-year students of the University of Reims Champagne-Ardenne (France). The first 16 months of the survey, which is due to run for 5 years, are analysed here. A self-report questionnaire was proposed to all first-year students during their mandatory preventive medicine consultation. The questionnaire kit comprised validated questionnaires evaluating addiction to alcohol, tobacco, cannabis, cocaine, amphetamines, solvents, tranquillizers, hallucinogens, opiates, other drugs, internet, and gambling or games of chance. Results: In total, 1139 students were included in this analysis; participation rate was $94 \%$ among all those invited to participate. Average age was $19 \pm 1$ years, male to female sex ratio was 0.54 . Among respondents, $18 \%$ were at risk of addiction to alcohol, $2.3 \%$ were addicted; $19.6 \%$ were smokers, and $5.5 \%$ were dependent. Cannabis was the most frequently used illicit substance, with $4.8 \%$ of students at risk, and 2 subjects addicted. For the internet, $11.6 \%$ of subjects were at risk, and $1.4 \%$ were addicted. By logistic regression, students receiving grants or whose parents have a low socio-professional category were at less risk of addiction to alcohol. We also found that students at risk were less likely to accept treatment. Conclusion: These initial findings show that certain addictive behaviours are particularly prevalent among first-year students, with identifiable risk factors or protective factors, thereby opening
\end{abstract}

*Corresponding author.

How to cite this paper: Andrea, G., Frédéric, D., Marie-Emmanuelle, K., Guillaume, K., Caroline, C., Moustapha, D. and Sébastien, G. (2016) Evaluation of Addiction among Students in First Year of a French University. Open Journal of Preventive Medicine, 6, 42-56. http://dx.doi.org/10.4236/ojpm.2016.61004 
avenues for preventive and therapeutic measures.

\title{
Keywords
}

\author{
Students, Addiction, Substance Abuse, Prevalence, France
}

\section{Introduction}

Addictive behaviours represent a major public health challenge [1]. University students are a population at particularly high risk of addiction due to their entry into the university context, often a stressful event that can lead to the emergence of addictive behaviours [2]. Addictive behaviours generate an important loss of time that could impact academic performances even if it's not always a measurable fact [3].

Available data from France stem mainly from three sources, namely a national health survey entitled "Baromètre Santé 2010" [4], which investigated consumption of licit and illicit substances in youngsters aged 15 to 30 years old, comparing students to active and inactive populations of similar age; secondly, from the "Escapad" survey of health and drug use carried out among 17-year olds attending their day of preparation for defence service (JAPD, journéed'appel à la défense) [5]; and lastly, from studies performed by student health insurance groups [6].

A few French studies have specifically investigated addictive behaviours in students, but most dealt with addiction to a particular substance [7], or specific addictive behaviours, without an overall perspective on addictive behaviours of all types [8] among the different university courses. Indeed, an overall approach is advocated by the public authorities, taking into account not only addictions to drugs, but also other, non-drug addictions. In addition, health authorities recommend investigating the social origins and lifestyle habits of students, as these could shed some light on the addictive profiles. This in turn might help to improve early detection of subjects potentially at risk or already dependent (i.e. addicts, a term increasingly used in the French language), with a view to initiating appropriate management [9].

In view of the paucity of data in this area, and in order to improve management of addiction among students, the University Department for Prevention Medicine and Health Promotion (Service Universitairede MédecinePréventiveet de Promotion de la Santé, SUMPPS) of the University of Reims Champagne-Ardenne in north-east France is conducting a 5-year survey within the framework of a larger project entitled "Addict-Free University". The main objective is to identify addicts or students at risk of addiction, and to investigate the social and lifestyle factors related to the risk of addictive behaviour. This article presents preliminary results from this survey.

\section{Methods}

\subsection{Study Design}

Cross-sectional survey in two phases. The first phase is descriptive, and describes the socio-demographic and socio-economic characteristics of the students surveyed, as well as the prevalence of drug and behavioural addictions. The second phase is analytic, and investigates the risk of addiction to alcohol in particular. This project is performed in collaboration between the SUMPPS and the research unit entitled "Observatoire du Suivi, de l'Insertion Professionnelle et de l'Evaluation (OSIPE)”, which provides the scientific know-how for analysis and performance of the study. The results presented here are from the first 16 months of the study (March 2013 to June 2014).

\subsection{Study Population}

The target population for the study was students in their first year of study at the University of Reims Champagne-Ardenne (URCA) who attended the mandatory preventive medicine consultation. All students had to be registered for the first time, in first year, in their first university qualification, be aged over 18 years, and be able to read, write and understand French without assistance. Exclusion criteria were: refusal to consent to participate, repeat students, and students who already completed the survey at a prior consultation. Six university sites participated, namely the Croix-Rouge campus in Reims; the faculty of Exact and Natural Sciences in Reims; the 
campus of the University Institute of Technology (Institut Universitaire de Technologie, IUT) in Châlons-enChampagne; the campus of the University Institute of Technology (IUT) in Charleville-Mézières, and two campuses in Troyes. Six disciplines were covered, namely Exact \& Natural Sciences; Arts \& Human Sciences; Law; Economic \& Management Sciences; University Institutes of Technology; and the first year of medical school (which is common to all students destined for medicine, pharmacy, dentistry, midwifery, as well as rehabilitation professions such as physiotherapy, ergotherapy and psychomotricity).

\subsection{Variables Recorded}

A computerized self-report questionnaire kit was proposed to eligible students before their consultation in preventive medicine. They completed the questionnaire in the waiting room on a dedicated computer. The completion time varied from 10 to 25 minutes according to their drug use habits. The study was approved by the National authority for the protection of privacy and personal data, and anonymity was guaranteed. Failure to respond to a question did not prevent completion of the rest of the questionnaire. The questionnaire was divided into two parts. The first part was similar to the registration form completed at registration in the University, and recorded the following variables:

- Age and sex

- Course and campus

- Nationality

- Academy where the student obtained their baccalaureate (high school diploma)

- Type of accommodation (living at home with parents, living with a family, student residence, sharing a flat with other students, living alone in rented accommodation or living maritally in own accommodation).

- Parents' profession:

o No profession/unemployed

o Manual labourers/employees

o Farmer

o Self-employed/shop-owner/owns a business

o Intermediate-level professionals/healthcare managers/middle management/technicians

o Primary or secondary school teacher/scientific professions

o Liberal professions/upper level management

o An additional variable combined the first two groups (unemployed, no profession or manual labourers).

- Is the student receiving a grant or not, and if yes, amount of the grant.

- Does the student work in addition to attending university.

In the second part, the student was requested to complete a series of validated questionnaires to identify potential addicts or subjects at risk of addiction to ten different substances (alcohol, tobacco, cannabis, cocaine, amphetamines, solvents, tranquillizers, hallucinogens, opiates, other drugs) and two behaviours (internet, and gambling for money/games of chance). The respective instruments used were: the Alcohol, Smoking and Substance Involvement Screening Test (ASSIST) to evaluate alcohol use [10]; the Fagerström test for tobacco use [11]; the Alcohol Use Disorders Identification Test (AUDIT) for other substances [12]; the Orman Internet Stress Scale [13] and the MINI International Neuropsychiatric Interview DSM-IV [14] for gambling and games of chance. Some self-report questions were also added, such as: “do you smoke?”, "have you ever consumed alcoholic beverages?”.

To evaluate smoking, the Fagerström test was used to identify only subjects who were dependent, and to evaluate the intensity of their physical dependence on nicotine (low, moderate, or high). However, subjects at risk were not identified. Certain questions from some tests were extracted and used as stand-alone variables, for example "binge drinking" for alcohol use (defined as at least six drinks on one occasion), and prevalence of use of various substances over the previous three months. Students were classed into two groups according to age (i.e. $<20$ years and $\geq 20$ years old), in order to investigate whether there were any differences in behaviours between younger and older students. Willingness to accept treatment was considered as a variable in its own right.

\subsection{Statistical Analysis}

Descriptive analysis of all available data was performed. Quantitative data are described as mean \pm standard deviation and qualitative variables as number (percentage). Univariate analysis was performed on four variables, namely: risk of addiction to alcohol, cannabis and internet, and degree of tobacco dependence (low, moderate or 
high according to the Fagerström test). The choice of these variables was justified by their high prevalence. Percentages were compared by univariate analysis using the Chi square or Fisher's exact test, as appropriate. Multivariate analysis was performed using binary logistic regression to identify independent risk factors for addiction to alcohol. We chose alcohol for the multivariate analysis since the sample size was largest for this substance. Results of the multivariate analysis are presented as odds ratios (OR) and 95\% confidence interval (95\% $\mathrm{CI})$. A p-value $<0.05$ was considered statistically significant. All analyses were performed using SAS version 9.3 (SAS Institute Inc., Cary, NC, USA).

\section{Results}

In total, 1230 subjects were invited to participate, of whom 74 refused consent, giving a participate rate of $94 \%$. Seventeen students were subsequently excluded because they were aged $<18$ years. Thus, 1139 students were included in this analysis, average age $19 \pm 1$ year, with a male-to-female sex ratio of 0.54 . Participation corresponded to $11.5 \%$ of all first registrations for the whole period; but participation was $26.5 \%$ of all students who attended the mandatory preventive medicine consultation for the university year 2013-2014.

Students from the city of Reims were over-represented in the sample, and the "Arts \& Humans Sciences" and "IUT" disciplines had the largest number of registrants. The majority of students were either living at home with their parents, or were living alone in an apartment, with similar proportions for each. Half of the participants were receiving a grant (Table 1). The professions of the students' parents are summarized in Table 2.

Table 1. Socio-demographic and socio-economic characteristics of first-time first-year students at the University of Reims Champagne-Ardenne, France, for university year 2013-2014.

\begin{tabular}{|c|c|c|}
\hline Variable & & $\mathrm{n}(\%)($ Total $=1139)$ \\
\hline \multirow{2}{*}{ Sex } & Male & $395(34.9)$ \\
\hline & Female & $736(65.1)$ \\
\hline \multirow{2}{*}{ Age } & $<20$ years & $1016(89.2)$ \\
\hline & $>$ or $=20$ years & 123(10.8) \\
\hline \multirow{2}{*}{$\begin{array}{l}\text { Academy where baccalaureate } \\
\text { was obtained }\end{array}$} & Reims & $880(77.3)$ \\
\hline & Other & $259(22.7)$ \\
\hline \multirow{2}{*}{ Nationality } & French & 1108 (97.5) \\
\hline & Other & $28(2.5)$ \\
\hline \multirow{4}{*}{ City where campus is located } & Reims & $912(80.5)$ \\
\hline & Charleville-Mézières & $14(1.2)$ \\
\hline & Châlons-en-Champagne & $29(2.6)$ \\
\hline & Troyes & $178(15.7)$ \\
\hline \multirow{6}{*}{ Discipline studied } & Exact \& natural sciences & $20(1.8)$ \\
\hline & Arts \& human sciences & 377 (33.3) \\
\hline & Law & $138(12.2)$ \\
\hline & Economics/management & $123(10.9)$ \\
\hline & Medicalschool $^{\mathrm{a}}$ & $224(19.8)$ \\
\hline & Institute of technology & $251(22.2)$ \\
\hline \multirow{6}{*}{ Type of accommodation } & Living with a family & $18(1.6)$ \\
\hline & Living at home & $428(37.7)$ \\
\hline & Sharing a flat & $128(11.3)$ \\
\hline & Living maritally & $47(4.1)$ \\
\hline & Living alone in rented accommodation & $437(38.5)$ \\
\hline & Studentresidence & $78(6.9)$ \\
\hline \multirow{2}{*}{ Income } & Workingwhile at university & $81(7.1)$ \\
\hline & Grant & $553(49.0)$ \\
\hline
\end{tabular}

${ }^{\mathrm{a}}$ First year of medical studies common to all students destined for medicine, pharmacy, dentistry, midwifery, and rehabilitation professions such as physiotherapy, ergotherapy and psychomotricity. 
Table 2. Socio-professional characteristics of the parents of students registered in first year at the University of Reims Champagne-Ardenne, France, for university year 2013-2014.

\begin{tabular}{lcccc}
\hline & Mother & Father & Bothparents $^{\mathrm{a}}$ & 1 parent $^{\mathrm{b}}$ \\
\cline { 2 - 5 } & $\mathrm{n}(\%)$ & $\mathrm{n}(\%)$ & $\mathrm{n}(\%)$ & $\mathrm{n}(\%)$ \\
\hline No profession/unemployed & $236(21.1)$ & $100(9.4)$ & $35(3.3)$ & - \\
Manuallabourers/employees & $435(38.9)$ & $387(36.3)$ & $215(20.4)$ & - \\
Farmer & $19(1.7)$ & $53(5.0)$ & $10(1.0)$ & - \\
Self-employed/shop-owner/owns a business & $62(5.6)$ & $146(13.7)$ & $24(2.3)$ & - \\
Intermediate-level professionals/healthcare & $179(16.0)$ & $169(15.9)$ & - & - \\
managers/administrative managers/technicians & $86(7.7)$ & $52(4.9)$ & $112(10.5)$ \\
Primary/secondaryteachers & $101(9.0)$ & $159(14.9)$ & - & $212(19.8)$ \\
Liberal professions/upper level management & $671(60.0)$ & $487(45.7)$ & $731(69.2)$ & - \\
Lowsocio-professionalcategory &
\end{tabular}

${ }^{\mathrm{a}}$ Both parents have the same profession; ${ }^{\mathrm{b}}$ One parent has the profession; ${ }^{\mathrm{c}}$ Group combining the first two groups, namely unemployed/no profession and manual labourers/employees.

The majority of students (88.3\%) reported that they had consumed alcohol before. Overall, 203 (18.0\%) were at risk of addiction, and 26 (2.3\%) were addicted to alcohol (Table 3), while 192 (16.9\%) reported binge drinking.

Regarding smoking habits, 223 (19.6\%) were smokers. According to the Fagerström test, 63 (5.5\%) were classed as dependent, with $23(2.0 \%)$ classed as requiring treatment (high and moderate dependence).

As shown in Table 3,14.3\% of respondents answered that they can used cannabis at least once in the previous 3 months, with 54 (4.75\%) students at risk of addiction, and 2 subjects $(0.2 \%)$ classed as addicts.

Regarding the internet, 131 (11.6\%) were at risk of addiction, and $16(1.41 \%)$ were considered as addicts.

Sixty-two subjects reported having taken tranquilizers in the previous 3 months, 13 had taken amphetamines, 7 had taken hallucinogens, 7 had taken solvents, 6 had taken cocaine, 3 had taken opiates and 6 had taken other substances including homeopathic substances and nitrous oxide (N20). No subject was found to be dependent.

Forty students reported that they gambled or played games of chance, of whom one was at risk of addiction and one other was classed as an addict.

Combinations of addictions were observed among our population of first-year students, particularly alcohol + tobacco, with 11 subjects (1.0\%) considered addicts. There were few combinations of addictions for other substances.

\subsection{Univariate Analysis}

Univariate analysis showed that among all respondents, $21.8 \%$ of men were at risk of alcohol addiction, and $15.9 \%$ of women $(\mathrm{p}<0.05)$.

Students in Chalons-en-Champagne were at significantly higher risk $(\mathrm{p}<0.05)$, whereas foreign students seemed to be a lower risk, as were those who obtained? Their Baccalaureate in academies other than Reims (Table 4). There was no difference in risk of alcohol addiction according to age, type of accommodation, and extra-curricular work.

We observed a borderline higher risk of addiction to alcohol when one parent had a liberal profession or management position $(22.8 \%$ versus $17.1 \%, \mathrm{p}=0.06)$. Conversely, when both parents were in the lower socioprofessional categories, there were fewer subjects at risk: $15.6 \%$ vs $24.1 \%, \mathrm{p}<0.001$. As shown in Table 4 , there were no other links between the parents' profession and risk of alcohol addiction. Students receiving grants appeared to be a lower risk, with $15.1 \%$ at risk vs $20.9 \%$ among those not receiving grants, $p=0.01$. Conversely, there was no correlation between the amount of the grant and the risk of addiction to alcohol. In terms of willingness to receive treatment, students classed at risk of alcohol addiction were significantly less willing to receive treatment $(12.5 \%$ vs $24.3 \%, \mathrm{p}<0.0001)$.

As regards tobacco dependence, univariate analysis did not show any difference in terms of sex, city where 
Table 3. Prevalence of addiction and students at risk of addiction for the different substances and behaviours among firstyear students at the University of Reims Champagne-Ardenne, France, for university year 2013-2014.

\begin{tabular}{|c|c|c|c|}
\hline Substance/behaviour & At risk ${ }^{a}$ (\%) & Addiction $^{\mathrm{b}} \mathrm{n}(\%)$ & $\begin{array}{c}\text { Use within previous } 3 \\
\text { months }^{\mathrm{c}} \mathrm{n}(\%)\end{array}$ \\
\hline Alcohol & $203(18.0)$ & $26(2.3)$ & - \\
\hline Tobacco & $0(0.0)$ & $63(5.5)$ & - \\
\hline Cannabis & $54(4.8)$ & $2(0.2)$ & $162(14.3)$ \\
\hline Cocaine & $2(0.2)$ & $0(0.0)$ & $6(0.5)$ \\
\hline Amphetamines & $8(0.7)$ & $0(0.0)$ & $13(1.2)$ \\
\hline Solvents & $3(0.3)$ & $0(0.0)$ & $7(0.6)$ \\
\hline Tranquillizers & $34(3.0)$ & $0(0.0)$ & $62(5.5)$ \\
\hline Hallucinogens & $5(0.4)$ & $0(0.0)$ & $7(0.6)$ \\
\hline Opiates & $1(0.1)$ & $0(0.0)$ & $3(0.3)$ \\
\hline Otherdrugs & $0(0.0)$ & $0(0.0)$ & $6(0.5)$ \\
\hline Internet & $131(11.6)$ & $16(1.4)$ & - \\
\hline Gambling/games of chance & $1(0.1)$ & $1(0.1)$ & - \\
\hline
\end{tabular}

a subjectsat risk of addiction; ${ }^{\mathrm{b}}$ Subjects classed as addicted; ' Subjects who reported use within the previous 3 months.

the student was studying, nationality, academy where they achieved their baccalaureate, type of accommodation, parents' profession, working in addition to studies, or grant status. Conversely, students studying economics were more tobacco-dependent than students from other disciplines, $11.4 \%$ vs $4.7 \%(p<0.01)$ and students in Arts \& Human sciences also tended to be dependent $(7.2 \%$ vs $4.5 \%, p=0.06)$. Students in first year of medical school were less dependent than students from other disciplines $(2.23 \%$ vs $6.16 \%, p<0.05)$. Students aged $\geq 20$ years were significantly more frequently dependent $(11.4 \%$ vs $4.8 \%, \mathrm{p}<0.01)$, and as observed for alcohol addiction, students classed as dependent were less likely to be willing to accept treatment $(2.8 \%$ vs $8.6 \%$, $\mathrm{p}<$ $0.001)$.

Univariate analysis of cannabis use showed that male students were at greater risk than females $(6.9 \%$ vs $3.7 \%, \mathrm{p}<0.05)$, and again, students at risk were less willing to accept treatment $(2.0 \%$ vs $7.9 \%, \mathrm{p}<0.001)$.

Regarding the internet, univariate analysis showed that students who had obtained their baccalaureate outside the academy of Reims were at great risk of addiction $(16.5 \%$ vs $10.3 \%, \mathrm{p}=0.01)$. Again, students at risk of addiction to internet were less willing to accept therapy ( $8.7 \%$ vs $14.9 \%$, $\mathrm{p}<0.001)$.

\subsection{Multivariate Analysis}

Binary logistic regression identified two independent factors that were significantly related to alcohol addiction, namely both parents having a low socio-professional category (OR 0.6, 95\% CI $0.44-0.93$ ), and willingness to accept therapy (OR 0.5, 95\% CI 0.33 - 0.63) (Table 5).

\section{Discussion}

The preliminary results presented here show that addiction to licit and illicit substances, as well as addictive behaviours, are widespread among university students. Among the substances studied, alcohol and tobacco are the most frequently consumed, in line with previous reports among university students in France and Europe [4] [6] [15]-[17]. These are followed by cannabis and internet use. We observed that $2.3 \%$ of students were alcoholdependent, and $18 \%$ were at risk of addiction, and these figures are also similar to findings from other surveys [6] [18]. Binge drinking appears to be on the rise among students in recent years. Indeed, a comparison between university students and non-student populations of the same age reveals that binge drinking, whose primary aim is to get drunk quickly, is more common among students [19]-[23]. In our sample, almost 17\% reported binge drinking. This phenomenon could be partially explained by the fact that students' perception of danger is differ- 
Table 4. Factors associated with risk of alcohol addiction by univariate analysis among first-year students at the University of Reims Champagne-Ardenne, France, for university year 2013-2014.

\begin{tabular}{|c|c|c|c|c|}
\hline \multirow[t]{2}{*}{ Variable } & & \multicolumn{3}{|c|}{ At risk of alcohol addiction } \\
\hline & & $\begin{array}{c}\text { Yes } \\
\text { n (\%) }\end{array}$ & $\begin{array}{c}\text { No } \\
\text { n (\%) }\end{array}$ & $\underset{n}{p}$ \\
\hline \multirow[t]{9}{*}{ Demographics } & Sex & & & $<0.05$ \\
\hline & Male & $84(21.8)$ & $301(78.2)$ & \\
\hline & Female & 117 (15.9) & $617(84.1)$ & \\
\hline & Nationality & & & $<0.05$ \\
\hline & French & $202(18.4)$ & 894 (81.6) & \\
\hline & Other & $1(3.6)$ & $27(96.4)$ & \\
\hline & Age & & & NS \\
\hline & $<20$ years & $176(17.5)$ & $830(82.5)$ & \\
\hline & $>$ or $=20$ years & $27(22.3)$ & $94(77.7)$ & \\
\hline \multirow[t]{3}{*}{ Baccalaureate } & Academy of Baccalaureate & & & $<0.05$ \\
\hline & Reims & $168(19.3)$ & $702(80.7)$ & \\
\hline & Other & 35 (13.6) & $222(86.4)$ & \\
\hline \multirow[t]{6}{*}{ Income } & Grant & & & 0.01 \\
\hline & Yes & $83(15.1)$ & $467(84.9)$ & \\
\hline & No & $119(20.9)$ & $451(79.1)$ & \\
\hline & Working while at university & & & NS \\
\hline & Yes & $18(22.2)$ & $63(77.8)$ & \\
\hline & No & $184(17.6)$ & $860(82.4)$ & \\
\hline \multirow[t]{12}{*}{ Campus location } & Reims & & & NS \\
\hline & Yes & $163(18.0)$ & $742(82.0)$ & \\
\hline & No & 38 (17.6) & $178(82.4)$ & \\
\hline & Châlons-en-Champagne & & & $<0.05$ \\
\hline & Yes & $10(34.5)$ & $19(65.5)$ & \\
\hline & No & $191(17.5)$ & $901(82.5)$ & \\
\hline & Charleville-Mézières & & & NS \\
\hline & Yes & $3(21.4)$ & $11(78.6)$ & \\
\hline & No & 198 (17.9) & $909(82.1)$ & \\
\hline & Troyes & & & NS \\
\hline & Yes & 25 (14.4) & $148(85.6)$ & \\
\hline & No & $176(18.6)$ & $772(81.4)$ & \\
\hline
\end{tabular}




\section{Continued}

\begin{tabular}{|c|c|c|c|c|}
\hline \multirow[t]{18}{*}{ Discipline } & Sciences & & & NS \\
\hline & Yes & $3(15.0)$ & $17(85.0)$ & \\
\hline & No & $198(18.0)$ & $903(82.1)$ & \\
\hline & Arts \& human sciences & & & NS \\
\hline & Yes & $68(18.3)$ & 304 (81.7) & \\
\hline & No & $133(17.8)$ & $616(82.2)$ & \\
\hline & Law & & & NS \\
\hline & Yes & 23 (16.8) & $114(83.2)$ & \\
\hline & No & $178(18.1)$ & 806 (81.9) & \\
\hline & Medicalschool & & & NS \\
\hline & Yes & $36(16.1)$ & 187 (83.9) & \\
\hline & No & 165 (18.4) & 733 (81.6) & \\
\hline & Institute of technology & & & NS \\
\hline & Yes & $50(19.9)$ & $201(80.1)$ & \\
\hline & No & $151(17.3)$ & $722(82.7)$ & \\
\hline & Economics & & & NS \\
\hline & Yes & $21(17.4)$ & $100(82.6)$ & \\
\hline & No & $180(18.0)$ & $820(82.0)$ & \\
\hline \multirow[t]{18}{*}{ Accommodation } & Living with a family & & & NS \\
\hline & Yes & $1(5.6)$ & $17(94.4)$ & \\
\hline & No & $201(18.2)$ & $906(81.8)$ & \\
\hline & Sharing a flat & & & NS \\
\hline & Yes & $220(15.8)$ & $107(84.3)$ & \\
\hline & No & $182(18.2)$ & $816(81.8)$ & \\
\hline & Living at home & & & NS \\
\hline & Yes & 75 (17.9) & $345(82.1)$ & \\
\hline & No & $127(18.0)$ & $578(82.0)$ & \\
\hline & Living maritally & & & NS \\
\hline & Yes & $9(19.2)$ & 38 (80.9) & \\
\hline & No & 193 (17.9) & $885(82.1)$ & \\
\hline & Living in rented accommodation & & & NS \\
\hline & Yes & $81(18.6)$ & $354(81.4)$ & \\
\hline & No & $121(17.5)$ & $569(82.5)$ & \\
\hline & Student residence & & & NS \\
\hline & Yes & $16(20.5)$ & $62(79.5)$ & \\
\hline & No & $186(17.8)$ & $861(82.2)$ & \\
\hline
\end{tabular}




\begin{tabular}{|c|c|c|c|c|}
\hline \multicolumn{5}{|l|}{ Continued } \\
\hline \multirow{15}{*}{$\begin{array}{l}\text { Profession common to } \\
\text { both parents }\end{array}$} & Unemployed/no profession & & & NS \\
\hline & Yes & $3(8.8)$ & $31(91.2)$ & \\
\hline & No & 188 (18.5) & 827 (81.5) & \\
\hline & Manual labourer/employee & & & NS \\
\hline & Yes & 34 (15.9) & $180(84.1)$ & \\
\hline & No & 157 (18.8) & $678(81.2)$ & \\
\hline & Agriculteur/exploitant & & & NS \\
\hline & Oui & $2(20.0)$ & $8(80.0)$ & \\
\hline & Non & 189 (18.2) & $850(81.8)$ & \\
\hline & Self-employed/business owner & & & NS \\
\hline & Yes & $5(20.8)$ & $19(79.2)$ & \\
\hline & No & $186(18.2)$ & 839 (81.9) & \\
\hline & Lowsocio-professional category & & & $<0.001$ \\
\hline & Yes & $113(15.6)$ & $613(84.4)$ & \\
\hline & No & $78(24.2)$ & 245 (75.9) & \\
\hline \multirow[t]{9}{*}{$\begin{array}{l}\text { Profession } \\
\text { of one parent }\end{array}$} & $\begin{array}{l}\text { Intermediate level professions or } \\
\text { administrative managers }\end{array}$ & & & NS \\
\hline & Yes & $56(19.6)$ & $229(80.4)$ & \\
\hline & No & 139 (17.9) & $639(82.1)$ & \\
\hline & Teachers & & & NS \\
\hline & Yes & $21(18.8)$ & $91(81.3)$ & \\
\hline & No & $173(18.3)$ & 773 (81.7) & \\
\hline & $\begin{array}{l}\text { Liberal professions/upper level } \\
\text { management }\end{array}$ & & & 0.06 \\
\hline & Yes & $48(22.8)$ & $163(77.3)$ & \\
\hline & No & $145(17.1)$ & 704 (82.9) & \\
\hline \multirow[t]{3}{*}{ Treatment } & Willing to accepttreatment & & & $<0.0001$ \\
\hline & Yes & $75(12.5)$ & $524(87.5)$ & \\
\hline & No & $128(24.3)$ & 399 (75.7) & \\
\hline
\end{tabular}

NS, non-significant.

ent from reality [24]. Univariate analysis showed that males were at greatest risk, which is supported by literature data indicating that men consume both greater amounts of alcohol, and more often [25]-[28]. Foreign students appear to be at lower risk of addiction, as do grant students and students whose parents are in the lower socio-professional classes. Indeed, these latter two factors are protective factors against alcohol addiction, although in all three cases, it is logical to suppose that such students have less financial means at their disposal, and have an obligation to achieve good academic results. Grants, for example, are only renewed if the students is conscientious and achieving good results. There have been other reports in the same vein in the literature [29]. Similarly, it has previously been reported in both French and European studies that having one or both parents with a high socio-professional status is a risk factor for drunkenness or regular alcohol consumption [30]-[34]. In our study, we did not observe any significant risk for students having one parent with an intellectual profession, but we did observe a borderline significant trend towards greater risk of alcohol addiction among students 
Table 5. Factors associated with risk of alcohol addiction by multivariate logistic regression among first-year students at the University of Reims-Champagne-Ardenne, France, for university year 2013-2014.

\begin{tabular}{llc}
\hline Variable & OR & $95 \%$ CI \\
\hline Age & 1.1 & {$[0.90-1.34]$} \\
Male sex & 0.8 & {$[0.60-1.17]$} \\
Nationality & 4.2 & {$[0.55-32.34]$} \\
Academywherebaccalaureateobtained & 0.7 & {$[0.47-1.10]$} \\
Parents' profession & 0.9 & {$[0.63-1.25]$} \\
Both parents unemployed/without profession & 0.6 & {$[0.17-1.94]$} \\
Both parents in low socio-professional category & 0.6 & {$[0.44-0.93]$} \\
Both parents have liberal professions & 1.2 & {$[0.78-1.76]$} \\
Grant & 0.8 & {$[0.57-1.19]$} \\
Willingness to accepttherapy & 0.5 & {$[0.33-0.63]$} \\
\hline
\end{tabular}

with at least one parent in the liberal professions or upper-level management, with an OR of 1.43 (95\% CI 0.99 $2.07, \mathrm{p}=0.06$ ). Again regarding the parents' profession, we noted that our sample differed from the general population, as reported in the 2012 census statistics from the National Institute of Statistics and Economic Studies (INSEE) in terms of distribution of professional activities. The lower socio-professional groups are underrepresented in our sample (52.9\% vs $71.7 \%$ ) due to a considerable under-representation of the unemployed/no profession category ( $15.3 \%$ vs $43.3 \%$ in the general population). Conversely, there is an over-representation of the manual labourer/employee category in our sample (37.6\% vs $28.4 \%$ ). We therefore purport that having parents in the lower socio-professional classes is likely only a protective factor against alcohol addiction in this specific student population. This finding may not be generalizable to the general French population. It is also noteworthy that there was a high percentage of students whose parents are farmers in our study as compared to the general population ( $3.4 \%$ vs $1 \%$ ), which could be explained by the fact that the area around the study sites is rich agricultural land, with, in particular, a large number of champagne vineyards.

Regarding the types of accommodation, we did not find any significant differences in our study, contrary to certain other authors who reported that leaving the parental home constituted a risk factor for alcohol and/or drug use [33]-[35]. Similarly, our data did not provide any evidence that students who work in addition to studying had a different level of risk. Indeed, literature data on this point are conflicting [36]. We also observed no evidence that older students ( $\geq 20$ years) might be at higher risk than their younger counterparts. This is in line with previous findings from other studies [37] [38] suggesting that indeed, the level of consumption and addiction among students in the latter years of their studies is not greater, and might even be decreased. Some authors have suggested that the use of psychoactive drugs and the risk of addiction are most salient in the first few months at university, when the student has to adapt to the new environment [2] [9].

Multivariate logistic regression analysis revealed only two factors significantly related to alcohol use, and both had a protective effect, namely lower socio-professional category of the parents, and willingness to accept therapy among students at risk.

In our study, approximately $20 \%$ of students reported that they were smokers. This is a much lower rate than the general rate of smokers among 15 to 30 years, which was estimated to be $44 \%$ in a national health survey in France in 2010 [4]. However, the lower rate observed here is concordant with the results of this same health survey, insofar as $23.2 \%$ of youngsters in school or university were reported to be smokers. In our study, $5.5 \%$ were classed as dependent, and $2 \%$ presented a moderate or high intensity of dependence, warranting treatment. Univariate analysis failed to find any significant differences between males and females, in line with recent trends in smoking habits among 17 year-olds, where the gap between the sexes has been closing among daily smokers [5] [39] [40]. Conversely, it would appear that older students (20 years and older) are more dependent [41], as are students studying economics or arts, contrary to medical school students, who appear to be at significantly lower risk [37]. Perhaps the fact that medical students are less dependent stems from their awareness of the deleterious consequences of smoking in health terms. Furthermore, some reports have suggested that stu- 
dents in arts or economics are less satisfied with their course choice and shows signs of poor stress management [2] [6].

Among the illicit substances investigated in our study, cannabis was the most widely used, with $14.3 \%$ of students reporting having used it within the previous 3 months, confirming previous reports [4] [42]-[44]. Among self-reported users, we observed that $0.2 \%$ were addicts, and $4.8 \%$ were at risk of addiction, with male students at significantly higher risk than females. The overall rates of use were somewhat lower than those reported in a similar study in Paris universities in 2003, where 6\% were found to be dependent [7]. This discrepancy could be partially explained by the fact there has reportedly been a decrease in regular consumption (defined as at least 10 times in the previous month) among students aged 15 to 30 years, falling from $6.2 \%$ of regular users in 2000 to $3.1 \%$ in 2010 [4]. In addition, the region of Champagne-Ardenne in general has lower rates of cannabis use among youngsters [4].

Internet addiction is a relatively recent phenomenon and we observed that $1.4 \%$ of students were addicts, and $11.6 \%$ at risk of addiction. Other studies have also reported a low rate of cyber-addicts [45]-[47]. The proportion of students observed to be at risk was quite high, and was similar to the $13 \%$ observed in a population of university students on Reunion island [8]. However, the questionnaire used in our study was not the same, and therefore, the results are likely not comparable. Univariate analysis did not bring to light any significant links with other variables, contrary to certain reports indicating that men are at greater risk of internet addiction [37].

In all types of addiction, we noted that students at risk are more reluctant to accept specific help, indicating that the transition to management is difficult despite early identification of at-risk subjects. This underscores the importance of brief interventions, which have been shown to be useful and provide an opportunity to inform students about the risks they incur, thereby reducing initial consumption [48] [49].

We observed the use of tranquillizers to be quite prevalent, with 5.5\% reporting use within the previous 3 months, and an over-representation of females. Similar findings have been reported in other French studies [18] where $5.2 \%$ of students were found to use tranquillizers. Indeed, in the Escapad study, the rate of use was $7.7 \%$ [5]. France is reportedly one of the countries with the highest rate of use of tranquillizers among adolescents [15], and indeed the number of students at risk of addiction in our study is non-negligible, at 3\%. However, it should be underlined that we made no distinction between psychotropic medication taken on prescription, and non-prescription use.

Few studies have investigated the use of other illicit substances, and even fewer have addressed at-risk use and addiction to such substances. In the sparse data that is available, the methods used to evaluate use are heterogeneous. In our study, we found low rates of use of other illicit substances in the previous 3 months, and low rates of at-risk use, in line with available data [6] [43]. We did not find any subjects to be dependent. Similarly, there were few multiple addictions overall, which seems to correspond with the fact that registration for university-level education is generally a context that distances youths from the various types of multiple drug use [50].

\section{Strongpoints and Limitations of the Study}

First-year university students are mainly young adults getting their first experience of responsibility, and this can render them particularly vulnerable to addictive behaviours. Entry into student life, the change of context, the fear of failure, and the many nights out at student parties make this population a group highly exposed to disorders linked to addictive behaviours.

Regarding the representativeness of our study sample, there is a discrepancy between the various university disciplines represented. Indeed, the arts and human sciences are over-represented in our sample, as compared with the number of first-time first-year students overall in the University of Reims Champagne-Ardenne (33.3\% versus $22.1 \%$ respectively), while the exact and natural sciences are clearly under-represented (1.8\% versus 7.1\%). Medical school (19.8\% vs 18.1\%) and law students (12.2\% vs $12.1 \%$ ) are well represented, but economics and management sciences (10.8\% vs $13.3 \%)$ and IUT students (22.1\% vs 27.3\%) are statistically significantly under-represented, despite relatively similar levels. The recruitment procedure could explain these discrepancies, since the most highly represented disciplines are those with the highest expected number of students. For example, arts and human sciences, and medical school students are seen for their preventive medicine consultation at the start of the university year because of the large number of students in these courses, whereas law students, who are well represented are only seen towards the end of the year. The differences could also stem from the fact that this is a multicentre survey. The overall rate of participation is low (11.5\% of first registra- 
tions), partially due to the fact that the first year of the survey (2012/2013) only included students seen in consultations between March and June, and many students did not attend this mandatory medical visit. In the 2013/2014 university year, the rate of participation among students who attended their mandatory medical visit was $26.7 \%$.

A number of other biases inherent to observational studies also deserve to be acknowledged. Firstly, this is a cross-sectional, self-reporting survey, which is thus vulnerable to the risk of interpretation and memory bias. This type of survey is also at risk of social desirability bias, with corresponding under-declaration of behaviours perceived as socially reprehensible, and over-representation of behaviours deemed to be socially acceptable. Additionally, our sample comprises a large proportion of students from Reims and its environs, which may represent a recruitment bias. Lastly, since this survey evaluates behaviours at a single, given time point, it precludes any analysis of trends in addictive behaviours over time and between students in different years of their respective courses.

In parallel to surveys among students investigating addictive behaviours, it appears necessary to propose interventions to improve identification and management of students at risk. Some guidelines exist already in terms of prevention of substance abuse [48] and consist in improving knowledge of the substances consumed and their potentially harmful effects. Our study proposes a method to identify subjects at risk using a questionnaire approach, so that appropriate management can be proposed where necessary. This underscores the role of the preventive medicine department as an important base where students can find an attentive ear to listen to their problems, and appropriate help, if desired. Indeed, a number of socio-demographic and socio-economic characteristics seem to be related to addictive behaviours, suggesting that administrative data collected at registration in the university could help to identify subjects potentially at risk at the outset. However, this hypothesis should be considered with caution, since further analysis of the full cohort at the end of the 5-year survey period is mandatory to confirm these findings and identify the profile of students at risk. In addition, the larger sample that will be available for analysis at the end of the survey may also shed light on other addictive behaviours or bring to light new associations between risk factors and addiction to licit and illicit substances.

\section{Conclusion}

As in the general population, addictive behaviours are prevalent among university students, and likely contribute to lower quality of life on several levels (e.g. personal, social, familial, academic). Our study shows that students were parents in the lower socio-professional categories are at less risk of addiction, while students found to be at risk of addictive behaviours are less willing to accept therapy. The implications for public health and the high cost of management of dependent subjects should also be taken into account. Our findings highlight the importance of implementing specific prevention programmes in this context in order to limit the risks of addiction, not only terms of substance abuse, but also addictive behaviours, such as abusive internet use and gambling. These findings remain to be confirmed by further analysis of the full survey before any such steps can be taken. Indeed, more in-depth analysis of the full dataset is warranted to identify other potential factors related to addiction.

\section{Acknowledgements}

- The authors would like to thank the nurses in the prevention medicine departments of the six participating campuses for their collaboration on this project.

- The authors thank the members of the University of Reims Champagne-Ardenne who made this project possible.

- The authors thank Dr Marie MASURE (ANPAA 51) for her collaboration.

- The authors thank Fiona ECARNOT (EA3920, University Hospital Besancon, France) for translation and editorial assistance.

\section{Conflict of Interest}

None.

\section{References}

[1] Mission interministérielle de lutte contre la drogue et la toxicomanie. Plan gouvernemental de lutte contre les drogues 
et les toxicomanies 2008-2011. Rapport du Premier Ministre. La Documentation Française, Paris, 2008.

[2] Grebot, E. and Barumandzadeh, T. (2005) Access to University: Stressfull Situation at the Onset Some Dysfunctional Coping Strategies. Annales Médico-Psychologiques, Revue Psychiatrique, 163, 561-567. http://dx.doi.org/10.1016/j.amp.2004.07.015

[3] Usman, N.H., Alavi, M. and Shafeq, S.M. (2014) Relationship between Internet Addiction and Academic Performance among Foreign Undergraduate Students. Procedia - Social and Behavioral Sciences, 114, 845-851. http://dx.doi.org/10.1016/j.sbspro.2013.12.795

[4] Beck, F. and Richard, J.B. (2010) Baromètre santé 2010: Les comportements de santé des jeunes. Inpes, Saint-Denis.

[5] Spilka, S., Le Nézet, O. and Tovar, M.L. (2012) Les drogues à 17 ans: Premiers résultats de l'enquête ESCAPAD 2011. Tendances, 79, 1-4.

[6] USEM (2011) La santé des étudiants en 2011. Fédération nationale des observatoires régionaux de santé, Paris.

[7] Simmat-Durand, L. (2008) Marijuana Use among Students in a Parisian University (2003-2004). Journal de Pédiatrie et de Puériculture, 21, 119-123. http://dx.doi.org/10.1016/j.jpp.2008.02.007

[8] Ricquebourg, M., Bernède-Bauduin, C., Dafreville, C., Stojcic, I., Vauthier, M. and Galland, M.C. (2013) Internet and Video Games among Students of Reunion Island in 2010: Uses, Misuses, Perceptions End Associated Factors. Revue d'Epidémiologie et de Santé Publique, 61, 503-512. http://dx.doi.org/10.1016/j.respe.2013.07.685

[9] Beck, F., et al. (2005) Les usages de produits psychoactifs des étudiants. Psychotropes, 11, 31-51.

[10] Saunders, J.B., Aasland, O.G., Babor, T.F., De La Fuente, J.R. and Grant, M. (1993) Development of the Alcohol Use Disorders Identification Test (AUDIT): WHO Collaborative Project on Early Detection of Persons with Harmful Alcohol Consumption-II. Addiction, 88, 791-804. http://dx.doi.org/10.1111/j.1360-0443.1993.tb02093.x

[11] Heatherton, T.F., Kozlowski, L.T., Frecker, R.C. and Fagerström, K.O. (1991) The Fagerström Test for Nicotine Dependence: A Revision of the Fagerstrom Tolerance Questionnaire. British Journal of Addiction, 86, 1119-1127. http://dx.doi.org/10.1111/j.1360-0443.1991.tb01879.x

[12] Humeniuk, R., Ali, R., Babor, T.F., Farrell, T.F., et al. (2008) Validation of the Alcohol, Smoking and Substance Involvement Screening Test (ASSIST). Addiction, 103, 1039-1047. http://dx.doi.org/10.1111/j.1360-0443.2007.02114.x

[13] Orman, M. Internet Stress Survey. Accessed 26 October 2014. http://www.stresscure.com/hrn/addiction.html

[14] American Psychiatric Association (1996) Mini DSM-IV. Guelfi, J., Traduction, Masson, Paris.

[15] Spilka, S. and Le Nézet, O. (2011) Premiers résultats du volet français de l'enquête European School Survey Project on Alcohol and OtherDrugs (ESPAD) 2011. http://www.ofdt.fr/BDD/publications/docs/eisxsss5.pdf

[16] European Monitoring Center for Drugs, Drug Addiction (EMCDDA) (2013) Trends and Development 2013. European Drug Report. Publications Office of the European Union, Luxembourg.

[17] Beck, F. and Legleye, S. (2009) Sociology and Epidemiology of Consumption of Psychoactive Substances in Adolescents. L'Encéphale, 35, S190-S201. http://dx.doi.org/10.1016/S0013-7006(09)73470-0

[18] Jagu, N. (2006) Etude sur les addictions (tabac, alcool, cannabis, ecstasy) et les troubles anxio-depréssifs chez les étudiants stéphanois à l'aide d'un auto-questionnaire. Thèse d'exercice, Médecine Générale, Saint-Etienne.

[19] Gill, J.S. (2002) Reported Levels of Alcohol Consumption and Binge Drinking within the UK Undergraduate Student Population Ever the Last 25 Years. Alcohol and Alcoholism, 36, 540-543.

[20] Kypri, K. and Langley, J.D. (2003) Perceived Social Norms and Their Relation to University Student Drinking. Journal of Studies on Alcohol and Drugs, 64, 829-834. http://dx.doi.org/10.15288/jsa.2003.64.829

[21] Gmel, G., Rehm, J. and Kuntsche, E.N. (2003) Binge Drinking in Europe: Definitions, Epidemiology, and Consequences. SUCHT, 49, 105-116. http://dx.doi.org/10.1024/suc.2003.49.2.105

[22] Lagleye, S., Beck, F., Peretti-Watel, P. and Chau, N. (2008) Usages de drogues des étudiants, chômeurs et actifs de 18-25 ans. Tendances, 62, 1-4.

[23] Jefferis, B., Power, C. and Manor, O. (2005) Adolescent Drinking Level and Adult Binge Drinking in a National Birth Cohort. Addiction, 100, 543-549. http://dx.doi.org/10.1111/j.1360-0443.2005.01034.X

[24] Kypri, K., Hallet, J., Howat, P., McManus, A., Mayock, B., Bowe, S. and Horton, N.J. (2009) Randomized Controlled Trial of Proactive Web-Based Alcohol Screening and Brief Intervention for University Students. Archives of Internal Medicine, 169, 1508-1514. http://dx.doi.org/10.1001/archinternmed.2009.249

[25] Idier, L., Décamps, G., Rascle, N. and Koleck, M. (2011) Comparative Study of Attraction, Incidence and Intensity of Male and Female Student's Addictive Behaviors. Annales Médico-Psychologiques, Revue Psychiatrique, 169, 517-522. http://dx.doi.org/10.1016/j.amp.2010.07.014

[26] Stock, C., Mikolajczyk, R., Bloomfield, K., Maxwell, A.E., Ozcebe, H., Petkeviciene, J., et al. (2009) Alcohol Con- 
sumption and Attitudes towards Banning Alcohol Sales on Campus among European University Students. Public Health, 123, 122-129. http://dx.doi.org/10.1016/j.puhe.2008.12.009

[27] Andersson, C., Johnsson, K.O., Berglund, M. and Ojehagen, A. (2007) Alcohol Involvement in Swedish University Freshmen Related to Gender, Age, Serious Relationship and Family History of Alcohol Problems. Alcohol and Alcoholism, 42, 448-455. http://dx.doi.org/10.1093/alcalc/agm008

[28] Granville-Chapman, J.E., Yu, K. and White, P.D. (2001) A Follow-Up Survey of Alcohol Consumption and Knowledge in Medical Students. Alcohol and Alcoholism, 36, 540-543. http://dx.doi.org/10.1093/alcalc/36.6.540

[29] Beck, F., Guillemont, J. and Legleye, S. (2009) L’alcoolisation des jeunes: L’Apport de l’approche épidémiologique. Actualité et Dossier en Santé Publique, 67, 9-15.

[30] Legleye, S., Spilka, S., Le Nezet, O. and Laffiteau, C. (2009) Les drogues à 17 ans, résultats de l'enquête ESCAPAD 2008. Tendances, 66, 1-6.

[31] World Health Organisation, Regional Office for Europe (2012) Social Determinants of Health and Well-Being among Young People. Health Behaviour in School-Aged Children (HBSC) Study: International Report from the 2009/2010 Survey. WHO Regional Office for Europe, Copenhagen.

[32] Spilka, S., Le Nezet, O., Beck, F., Guignard, R. and Rodeau, E. (2012) Alcool, tabac, cannabis et autres drogues illicites. In: Godeau E., Navarro F. and Arnaud C., Eds., La Santé des collégiens en France/2010, Inpes, Saint-Denis, 147-181.

[33] Bullock, S. (2004) Alcohol, Drugs and Student Lifestyle. A Study of the Attitudes, Beliefs and Use of Alcohol and Drugs among Swedish University Students (SoRAD-Research Report No. 21). Centre for Social Research on Acohol and Drugs, Stockholm.

[34] Dantzer, C., Wardle, J., Fuller, R., Pampalone, S.Z. and Steptoe, A. (2006) International Study of Heavy Drinking, Attitudes and Sociodemographic Factors in University Students. Journal of American College Health, 55, 83-89. http://dx.doi.org/10.3200/JACH.55.2.83-90

[35] Caamaño-Isorna, F., Corral, M., Parada, M. and Cadaveira, F. (2008) Factors Associated with Risky Consumption and Heavy Episodic Drinking among Spanish University Students. Journal of Studies on Alcohol and Drugs, 69, 308-312. http://dx.doi.org/10.15288/jsad.2008.69.308

[36] Wicki, M., Kuntsche, E. and Gmel, G. (2010) Drinking at European Universities? A Review of Students’ Alcohol Use. Addictive Behaviors, 35, 913-924. http://dx.doi.org/10.1016/j.addbeh.2010.06.015

[37] Moaouad, J., Kazour, F., Haddad, R., Rouhayem, J., Chammai, R. and Richa, S. (2012) Chemical and Behavioural Addiction of Medical Students. Comparative Study in Libanese Students. L'Encéphale, 38, 467-472. http://dx.doi.org/10.1016/j.encep.2011.12.010

[38] Engs, R.C. and Van Teijlingen, E. (1997) Correlates of Alcohol, Tobacco and Marijuana Use among Scottish Postsecondary Helping-Profession Students. Journal of Studies on Alcohol and Drugs, 58, 435-444. http://dx.doi.org/10.15288/jsa.1997.58.435

[39] Dupuy, G., Vorspan, F. and Lépine, J.P. (2009) Epidemiology of Addictive Substances’ Use: Results of French Studies and International Perspectives. Annales Médico-Psychologiques, Revue Psychiatrique, 167, 498-503. http://dx.doi.org/10.1016/j.amp.2009.07.002

[40] Fernandez, L. and Letourmy, F. (2007) Le tabagisme féminin. In: Fernandez, L. and Letourmy, F., Eds., De l’initiation au sevrage, Armand Colin, Paris, 53-55.

[41] Guagliardo, V., Peretti-Watel, P., Combes, J.B., Obadia, Y. and Verger, P. (2009) Facteurs socio-démographiques et économiques associés aux usages de tabac, d'alcool et de cannabis chez des étudiants en première année d'université en région Paca. Bulletin Epidémiologique Hebdomadaire, 5, 53-56.

[42] Morvan, Y., Rouvier, J., Olié, J.P., Lôo, H. and Krebs, M.O. (2009) Student’s Use of Illicit Drugs: A Survey in a Preventive Health Service. L'Encéphale, 35, S202-S203. http://dx.doi.org/10.1016/S0013-7006(09)73471-2

[43] Adlaf, E.M., Gliksman, L., Demers, A. and Newton-Taylor, B. (2003) Illicit Drug Use among Canadian University Undergraduates. Canadian Journal of Nursing Research, 35, 24-43.

[44] European Monitoring Centre for Drugs, Drug Addiction (EMCDDA) (2013) Trends and Development 2013. European Drug Report. Publications Office of the European Union, Luxembourg.

[45] Décamps, G., Idier, L. and Battaglia, N. (2013) Personality and Addictive Profiles: A Study of Substance Use and Behavioral Addictions among College Students. Journal de Thérapie Comportementale et Cognitive, 23, 73-80. http://dx.doi.org/10.1016/j.jtcc.2013.04.001

[46] Décamps, G. and Perrin, L. (2010) Les multiples visages de l'addiction à Internet: Le cas d'un étudiant à la recherche de partenaires sexuels. In: Fernandez, L., Ed., Psychopathologie des addictions: Douze cas cliniques, Editions In Press, Paris, 239-269. 
[47] Niemz, K., Griffiths, M. and Banyard, P. (2005) Prevalence of Pathological Internet Use among University Students and Correlations with Self-Esteem, the General Health Questionnaire (GHQ), and Deshinibition. CyberPsychology \& Behavior, 8, 562-570. http://dx.doi.org/10.1089/cpb.2005.8.562

[48] Moyer, A., Finney, J.W., Swearingen, C.E. and Vergun, P. (2002) Brief Interventions for Alcohol Problems: A Meta-Analytic Review of Controlled Investigations in Treatment-Seeking and Non-Treatment-Seeking Populations. Addiction, 97, 279-292. http://dx.doi.org/10.1046/j.1360-0443.2002.00018.x

[49] Desjardin, N., D’Amours, G., Poissant, J., et al. (2008) Avis scientifique sur les interventions efficaces en promotion de la santé mentale et en prévention des troubles mentaux. Institut National de Santé Publique du Québec. https://www.inspq.qc.ca/pdf/publications/789_Avis_sante_mentale.pdf

[50] Beck, F., Legleye, S. and Spilka, S. (2008) Polyconsommation de substances psychoactives (alcool, tabac et cannabis) dans la population générale française en 2005. La Presse Médicale, 37, 207-215. http://dx.doi.org/10.1016/j.lpm.2007.07.011 